\title{
C57BL/6 Mice Infected with Neospora caninum During Administration of Progesterone Show Bias Toward Type 2 Immune Response
}

\author{
Rika KANO ${ }^{1) *}$, Akimasa KUDO ${ }^{1)}$, Hikaru KAMIYA ${ }^{1)}$, Yoshiyasu KOBAYASHI'), Ryuichiro MAEDA ${ }^{1)}$ and \\ Yoshitaka OMATA ${ }^{1)}$ \\ ${ }^{1)}$ Departments of Basic Veterinary Science and ${ }^{2)}$ Veterinary Pathobiological Science, School of Veterinary Medicine, Obihiro University \\ of Agriculture and Veterinary Medicine, Obihiro 080-8555, Japan
}

(Received 13 February 2007/Accepted 3 July 2007)

ABSTRACT. To clarify the role of progesterone in the development of immune responses during pregnancy against Neospora caninum infection, C57BL/ 6 mice were given a progesterone pellet, and measured on Interferon- $\gamma$ and interleukin-4 production following the infection. IFN- $\gamma$ production in the prescribed group was significantly lower than that in the intact group on day 40 post administration. IL-4 producing cell population in the prescribed group was larger than that in the intact group. These results suggest that progesterone may alter the balance of cytokine production, and that the bias toward type 2 immune response may remain for a certain period after the infection. KEY WORDS: immune responses, Neospora caninum, progesterone.

J. Vet. Med. Sci. 69(10): 1095-1097, 2007

Neospora caninum causes severe neuromuscular disease in companion animals, and abortion, stillbirth and congenital infection in livestock [1]. In non-pregnant animals, the type 1 immune response has been reported to play an important role in protecting against parasite development $[4,16]$. In mouse neosporosis, Long and Baszler [8] hypothesized that induction of maternal type 1 immune response against $N$. caninum might prevent vertical transmission and demonstrated that modulation of type 2 cytokines by giving antiIL-4 monoclonal antibodies before pregnancy could reduce the frequency of vertical transmission. Quinn et al. [13] examined the characterization of the immune response against $N$. caninum infection in the pregnant mouse, and suggested that control of transplacental transmission and fetal loss are associated with the bias of the cell-mediated immune response during pregnancy. However, the mechanisms of vertical transmission and repeated abortion in the chronic stage of the infection are still unknown. Rettigner et al. [14] studied on the vertical transmission and the immune response in the mice with $N$. caninum chronically infected during pregnancy, and concluded that reactivation of chronic infection during pregnancy seemed to be not consecutive to an immunodepression or a marked Th1-Th2 bias. In our own research, we observed a high frequency of vertical transmission in BALB/c mice infected with $N$. caninum when the mice had been infected during pregnancy and then re-bred in the chronic stage of the infection [12]. It has also been reported that the mice infected during pregnancy

\footnotetext{
* Present addRess: Kano, R., Laboratory of Infectious Diseases, Department of Disease Control, Graduate School of Veterinary Medicine, Hokkaido University, Kita-Ku, Sapporo, Hokkaido, 060-0818, Japan

**CoRrespondence to: Omata, Y., Department of Basic Veterinary Science, School of Veterinary Medicine, Obihiro University of Agriculture and Veterinary Medicine, Inada-cho, Obihiro 080-8555, Japan. e-mail: yomata@obihiro.ac.jp
}

retained a bias toward type 2 immune response in the recrudescence of the infection [3].

During pregnancy, it is known that the production and secretion levels of progesterone rise substantially, and it plays an important role in the bias toward the type 2 immune response which facilitates the maintenance of pregnancy [2, $15]$. In the present study, we focused on the role of progesterone in regulating the balance between type 1 and type 2 immune responses against $N$. caninum infection, and determined whether the bias remained in the later stage of infection and after re-infection. Regarding susceptibility and the immune response against $N$. caninum in inbred mice, Long et al. [9] measured IFN- $\gamma$ and IL-4 levels in $N$. caninumstimulated cultures of splenocytes from BALB/c, C57BL/6 and B10.D2 mice, and showed clearly that the B10.D2 mice were type 1 responders and the BALB/c mice were type 2 responders, while $\mathrm{C} 57 \mathrm{BL} / 6$ mice produced both cytokines. We therefore examined cytokine production activity in nonpregnant C57BL/6 mice which were prescribed a progesterone pellet or not, before infection in order to determine the effect of progesterone to the immune response in the later stage of the infection. Our results suggest that progesterone maintain a bias toward the type 2 immune response in the recrudescence of the infection.

Eight-week-old female C57BL/6 mice were purchased from Japan CLEA (Tokyo, Japan). Bovine angio-endothelial cells were cultured in Dulbecco's modified Eagle's medium containing $10 \%$ fetal bovine serum (DMEM10\%FBS), and tachyzoites of $N$. caninum derived from sheep $[6,7]$ were maintained by continuous passage in the BAE cell cultures and suspended in phosphate-buffered saline (PBS)

One group consisting of 5 mice (group 1) were inoculated intraperitoneally with $2 \times 10^{6} \mathrm{~N}$. caninum tachyzoites. Another group of mice (group 2) were prescribed a 21-day time release progesterone pellet $(25 \mathrm{mg} /$ pellet; Innovative 
Research of America, Sarasota, FL) subcutaneously, as described by Moro et al. [11]. On day 7 post administration, they were inoculated intraperitoneally with the same dose of tachyzoites as group 1. As controls, mice were either prescribed a progesterone pellet (group 3) or no pellet (group 4). For the examination on the immune response in the recrudescence phase, the mice of groups 1 and 2 were reinoculated with the same dose of tachyzoites on day 40 post inoculation. Spleens obtained from the inoculated and noninoculated mice on day 21 and 40 post administration, and on day 5 post re-inoculation were homogenized using a stainless steel mesh. Then erythrocytes were removed by treatment with $0.83 \% \mathrm{NH}_{4} \mathrm{Cl}$ solution, and the homogenates were washed with DMEM 3 times. To isolate the $\mathrm{CD}^{+} \mathrm{T}$ cell subset, magnetic bead cell sorting using anti-CD4 ${ }^{+}$ monoclonal antibody coated beads (BDTM IMag Anti-CD4 Particles-DM: BD Biosciences Pharmingen, San Diego, $\mathrm{CA}$ ) was conducted according to the manufacturer's instructions. The $\mathrm{CD}^{+}$cell populations obtained were more than $90 \%$ pure as determined by flow cytometry (EPICS XLADC; Beckman Coulter, Inc., Fullerton, CA). The cells were suspended to $6 \times 10^{6} \mathrm{cells} / \mathrm{m} l$, and then some were subjected to ELISPOT using an ELISPOT assay kit (BD) to examine the IL-4 producing cell population. The rest were incubated for $48 \mathrm{hr}$, then the supernatants were stored at $-80^{\circ} \mathrm{C}$ until assay for IFN- $\gamma$ production using an ELISA kits (ENDOGEN, Inc, Cambridge, MA). Both assays were conducted according to the manufacturer's instructions. To examine the $\mathrm{CD}^{+}$and $\mathrm{CD}^{+}$cell populations, $10^{6}$ cells in optimally diluted FITC-conjugated monoclonal antibodies for detection of $\mathrm{CD}^{+}$(GK1.5; BD) and $\mathrm{CD}^{+}$(53-6.7; BD) were incubated for $30 \mathrm{~min}$ on ice, then washed with chilled PBS, and suspended in propidium iodide-containing PBS. Rat $\operatorname{IgG}_{2 \alpha} \kappa$-isotype was used as the negative control. All experiments were performed in triplicate and repeated at least twice. Data from each experiment were evaluated using the Student's $t$-test. The level of significance in all analysis was $95 \%$.

The mean numbers of spleen cells and $\mathrm{CD}^{+}$and $\mathrm{CD}^{+}$ cell populations in the mice in each group $(n=5)$ are shown in Table 1. The numbers of spleen cells obtained from the infected mice (groups 1, and 2) were greater than that for the non-infected mice (groups 3, and 4). No significant difference was observed between the intact mice (group 1) and the progesterone prescribed mice (group 2) in this respect. The $\mathrm{CD}^{+}$cell population of the infected mice on day 21 post administration was smaller than that in non-infected mice. On day 40 post administration, the $\mathrm{CD}^{+}$cell population in the progesterone prescribed mice was relatively smaller than that of the intact mice. As shown in Fig. 1, IFN- $\gamma$ production was observed in the spleen cells of infected mice on day 21 post administration. Although the value in the group 2 was relatively lower than that in the group 1, the difference was not significant. In contrast, the group 1 showed greater IFN- $\gamma$ production on day 40 than on day 21 . A high level of IL-4 production was observed in both groups 1 and 2 on day 21 , but this decreased markedly in both groups on day 40 . In order to determine whether the reduction in IFN- $\gamma$ production in the group 2 was due to a bias toward the type 2 immune response, the mice of the groups 1 and 2 were reinoculated with the tachyzoites, and IFN- $\gamma$ and IL-4 production in the $\mathrm{CD}^{+}$cells of the mice was examined on day 5 post re-inoculation. The ELISPOT assay was used to examine IL-4 production at the cellular level. At that time, IFN$\gamma$ production was significantly higher in the group 1 than in the group 2 (Fig. 2), whereas, the IL-4 producing cell population in the group 2 was greater than that of the group 1 (Fig. 3). Little or no production of IFN- $\gamma$ or IL- 4 was observed in the non-infected mice groups.

In the present study, spleen cells of the progesterone prescribed mice showed a remarkable reduction in IFN- $\gamma$ production following infection, suggesting that progesterone may attenuate the type 1 immune response in mice till at least day 40 post administration. Interestingly, the immune response following re-infection was characterized by lower production of IFN- $\gamma$ and a greater population of IL-4 producing $\mathrm{CD}^{+}$cells, which means that the spleen $\mathrm{CD}^{+}$cells of the progesterone prescribed mice showed a bias toward the type 2 immune response. These results are consistent with the previous finding that the infected mice during pregnancy keep down-regulating type 1 cytokine production, resulting in a high rate of vertical transmission [3]. We were unable to clarify the precise mechanism for the bias in the present study, but one possibility is that the bias toward the type 2 immune response in the infected mice during pregnancy may be mediated by progesterone. Occurring in the acute stage of the infection, this bias may still remain in its later stages.

Table 1. Total cells and $\mathrm{CD}^{+} / \mathrm{CD}^{+}$cell populations in spleens of the mice inoculated with $N$. caninum

\begin{tabular}{|c|c|c|c|c|c|c|c|c|c|}
\hline \multirow{3}{*}{$\begin{array}{l}\text { No. } \\
\text { Group }\end{array}$} & \multicolumn{3}{|c|}{ Day 21 post-implant } & \multicolumn{3}{|c|}{ Day 40 post-implant } & \multicolumn{3}{|c|}{ Day 7 post-reinoculation ${ }^{\text {a) }}$} \\
\hline & \multirow{2}{*}{$\begin{array}{l}\text { spleen cells } \\
\left(\times 10^{7}\right)\end{array}$} & \multicolumn{2}{|c|}{ Cell populations (\%) } & \multirow{2}{*}{$\begin{array}{l}\text { spleen cells } \\
\qquad\left(\times 10^{7}\right)\end{array}$} & \multicolumn{2}{|c|}{ Cell popoulatinos (\%) } & \multirow{2}{*}{$\begin{array}{l}\text { spleen cells } \\
\quad\left(\times 10^{7}\right)\end{array}$} & \multicolumn{2}{|c|}{ Cell populations $(\%)$} \\
\hline & & $\mathrm{CD}^{+}$ & $\mathrm{CD} 8^{+}$ & & $\mathrm{CD}^{+}$ & $\mathrm{CD}^{+}$ & & $\mathrm{CD}^{+}{ }^{+}$ & $\mathrm{CD}^{+}$ \\
\hline N. caninum infected & & & & & & & & & \\
\hline 1) intact & $15 \pm 1.2$ & $10.6 \pm 0.5$ & $20.2 \pm 6.1$ & $15.5 \pm 2.0$ & $18.6 \pm 0.2$ & $16.7 \pm 1.1$ & $16.2 \pm 6.4$ & $17.3 \pm 1.8$ & $15.8 \pm 2.7$ \\
\hline $\begin{array}{l}\text { 2) Progesterone implant } \\
\text { Non-infected }\end{array}$ & $19 \pm 2.3$ & $7.1 \pm 1.3$ & $16.5 \pm 3.4$ & $17.7 \pm 1.9$ & $13.7 \pm 0.4$ & $13.1 \pm 1.8$ & $16.1 \pm 3.4$ & $14.5 \pm 2.7$ & $14.0 \pm 2.8$ \\
\hline 3) intact & $6.9 \pm 2.0$ & $17.3 \pm 2.9$ & $19.8 \pm 1.1$ & $7.1 \pm 2.7$ & $18.1 \pm 0.1$ & $15.1 \pm 1.1$ & ND. ${ }^{b)}$ & ND. & ND. \\
\hline 4) Progesterone implant & $13.8 \pm 1.1$ & $15.5 \pm 2.2$ & $8.2 \pm 0.6$ & $10.7 \pm 1.5$ & $18.5 \pm 0.2$ & $19.6 \pm 4.7$ & ND. & ND. & ND. \\
\hline
\end{tabular}

a) Reinoculated with $2 \times 10^{6} \mathrm{~N}$. caninum.

b) Not done. 


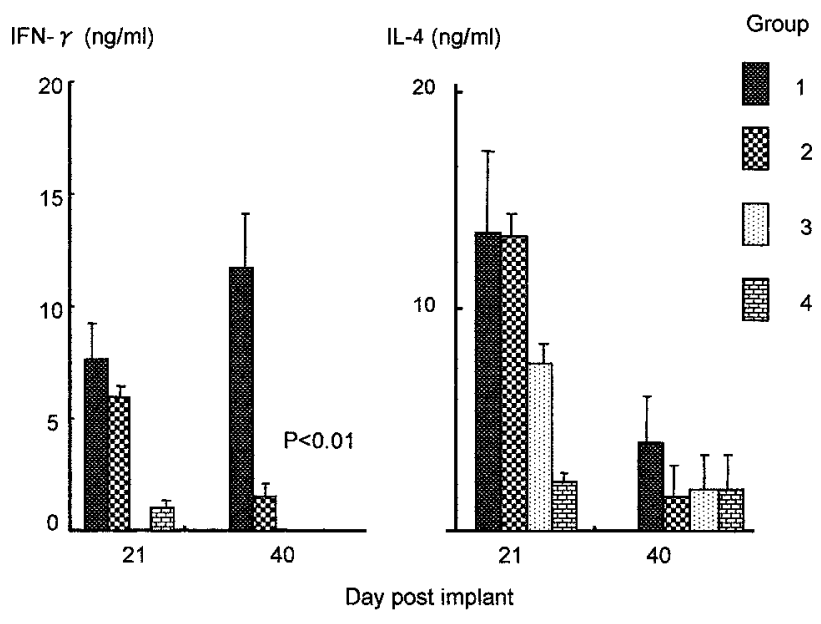

Fig. 1. Interferon- $\gamma$ and IL-4 levels in the supernatants of spleen cell cultures of the mice inoculated with $N$. caninum during period of progensterone administration.

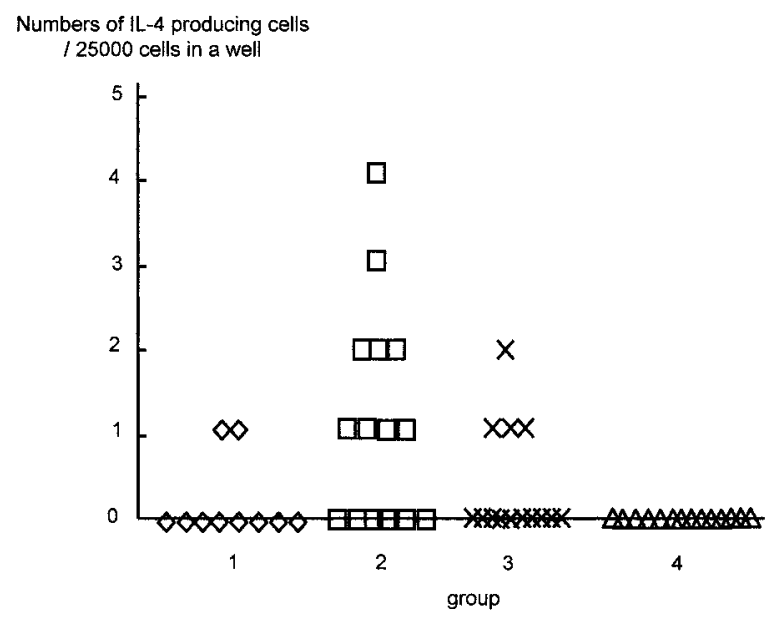

Fig. 3. ELISPOT assay for IL-4 producing cell populations in the $\mathrm{CD}^{+}$cells of the mice reinoculated with $N$. caninum. Sampling was on day 5 post reinoculation.

In the present study, we obtained no data to explain the transplacental transmission mechanism in chronic infection. In previous research, Miyaura and Iwata [11] demonstrated that glucocorticoid exerted a similar effect to that of progesterone on the development of the immune response. On the other hand, Kobayashi et al. noted that the administration of 17- $\gamma$ oestradiol, progesterone, and/or corticosterone did not reactivate infection [5]. To better understand the transplacental transmission mechanism in chronically infected animals, further studies are necessary to investigate the synergistic effects of other pregnancy-associated hormones and factors that are responsible for the reactivation of chronic infection on the development of immune response.

This study was supported in part by Grant-in-Aid for Sci-

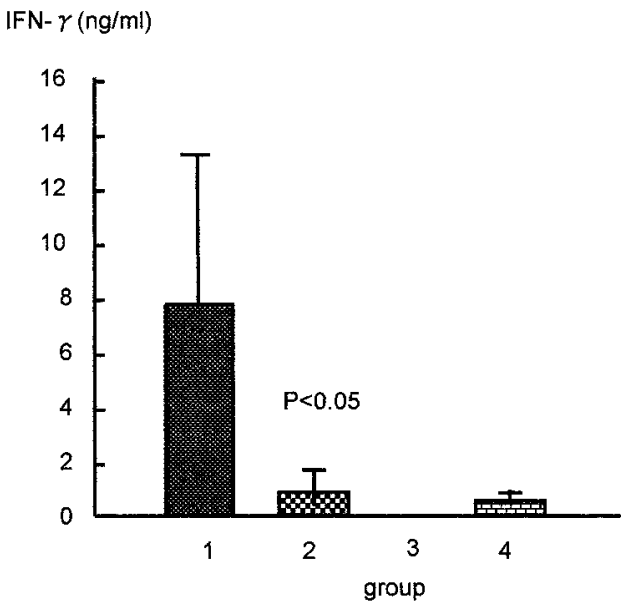

Fig. 2. Interferon- $\gamma$ levels in the supernatants of $\mathrm{CD}^{+}$cell cultures of reinoculated with $N$. caninum. Sampling was on day 5 post reinoculation.

entific Research (The 21st Century Center of Excellence Program) from the Ministry of Education, Culture, Sports, Science, and Technology of Japan.

\section{REFERENCES}

1. Dubey, J. P. and Lindsay, D. S. 1996. Vet. Parasitol. 67: 1-59.

2. Entrican, G. 2002. J. Comp. Pathol. 126: 79-94.

3. Kano, R., Masukata, Y., Omata, Y., Kobayashi, Y., Maeda, R. and Saito, A. 2005. Vet. Parasitol. 129: 159-164.

4. Khan, I. M., Schwartzman, J. D., Fonseka, S. and Kasper, L. H. 1997. Exp. Parasitol. 85: 24-34.

5. Kobayashi, A., Katagiri, S., Kimura, T., Ochiai, K. and Umemura, T. 2002. J. Vet. Med. Sci. 64: 773-777.

6. Kobayashi, Y., Yamada, M., Omata, Y., Koyama, T., Saito, A., Matsuda, T., Okuyama, K., Fujimoto, S., Furuoka,H. and Matsui, T. 2001. J. Parasitol. 87: 434-436.

7. Koyama, T., Kobayashi, Y., Omata, Y., Maeda, M., Furuoka, H., Maeda, R., Matsui, T., Saito, A.and Mikami, T. 2001. J. Parasitol. 87: 1486-1488.

8. Long, M. T. and Baszler, T. V. 2000. J. Immunol. 164: 47684774.

9. Long, M. T., Baszler, T. V. and Mathison, B. A.1998. J. Parasitol. 84: 316-320.

10. Miyaura, H. and Iwata, M. 2002. J. Immunol. 168: 1087-1094.

11. Moro, M. H., J. Bjornsson, E. V. Marietta, E. K. Hofmeister, J. J. Germer, E. Bruinsma, C. S. David, D. and Persing, H. 2001. J. Immunol. 166: 7404-7409.

12. Omata, Y., Nidaira, M., Kano, R., Kobayashi, Y., Koyama, T., Furuoka, H., Maeda, R., Matsui, T. and Saito, A. 2004. Vet. Parasitol. 121: 323-328.

13. Quinn, H. E., Miller, C. M. D. and Ellis, J. T. 2004. Int. J. Parasitol. 34: 723-732.

14. Rettigner, C., De Meerschman, F., Focant, C., Vanderplasschen, A. and Losson, B. 2004. Parasitology 128: 149-160.

15. Roberts, C. W., Walker, W. and Alexander, J. 2001. Clin. Microbiol. Rev.14: 476-488.

16. Tanaka, T., Hamada, T., Inoue, N., Nagasawa, H., Fujisaki, K., Suzuki, N. and Mikami, T. 2000. Vet. Parasitol. 90: 183-191. 